This article was downloaded by: [Australian National University]

On: 10 December 2013, At: 18:18

Publisher: Routledge

Informa Ltd Registered in England and Wales Registered Number: 1072954 Registered

office: Mortimer House, 37-41 Mortimer Street, London W1T 3J H, UK

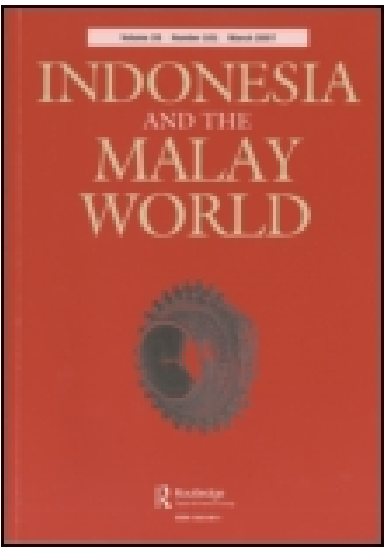

Indonesia and the Malay World

Publication details, including instructions for authors and subscription information:

http:// www. tandfonline.com/loi/ cimw20

\title{
DIFFERENT PERSPECTIVES ON THE RESISTANCE OF A MALAY STATE MEMPAWAH 1787-1808
}

W. G. Miller

Published online: 19 Aug 2013.

To cite this article: W. G. Miller (2013) DIFFERENT PERSPECTIVES ON THE RESISTANCE OF A MALAY STATE MEMPAWAH 1787-1808, Indonesia and the Malay World, 41:121, 348-369, DOI: 10.1080/13639811.2013.830857

To link to this article: http:// dx. doi.org/ 10.1080/13639811.2013.830857

\section{PLEASE SCROLL DOWN FOR ARTICLE}

Taylor \& Francis makes every effort to ensure the accuracy of all the information (the "Content") contained in the publications on our platform. However, Taylor \& Francis, our agents, and our licensors make no representations or warranties whatsoever as to the accuracy, completeness, or suitability for any purpose of the Content. Any opinions and views expressed in this publication are the opinions and views of the authors, and are not the views of or endorsed by Taylor \& Francis. The accuracy of the Content should not be relied upon and should be independently verified with primary sources of information. Taylor and Francis shall not be liable for any losses, actions, claims, proceedings, demands, costs, expenses, damages, and other liabilities whatsoever or howsoever caused arising directly or indirectly in connection with, in relation to or arising out of the use of the Content.

This article may be used for research, teaching, and private study purposes. Any substantial or systematic reproduction, redistribution, reselling, loan, sub-licensing, systematic supply, or distribution in any form to anyone is expressly forbidden. Terms \& Conditions of access and use can be found at http://www.tandfonline.com/page/termsand-conditions 


\title{
DIFFERENT PERSPECTIVES ON THE RESISTANCE OF A MALAY STATE MEMPAWAH 1787-1808
}

\begin{abstract}
A variety of sources may be consulted to examine a period of changing political and economic status in the west Borneo state of Mempawah between 1787 and 1808. These sources include traditional Malay histories, 19th-century Dutch accounts of events, 18th-century Malay letters and recent post-independence local histories. They reveal a diversity of perspectives on the events taking place and different interpretations of the personalities involved. The traditional ruling family of Mempawah maintained a considerable degree of influence over large areas of the state for a longer period than has previously been acknowledged, though it was the competition of Pontianak which ultimately proved the most important factor in the decline of Mempawah.
\end{abstract}

Keywords: Mempawah; Pontianak; Sayid Kassim; Adi Jaya Kesuma; Syarif Abd al-Rahman; historical relativism.

History is the reconstitution by and for those who are living of the life of those who are dead.

(Raymond Aron 1959: 54)

\section{Introduction}

In 1787, Mempawah was a flourishing state, or negeri, ${ }^{1}$ on the west coast of Borneo (Figure 1). Its capital, situated on the Mempawah river, was a leading port of the region. During the following decades its unity, political power and economic activity

\footnotetext{
*Email: gmiller@grapevine.com.au

${ }^{1}$ Negeri is the term used in contemporary indigenous documents. Simply for convenience, the inappropriate modern term 'state' is used. Negeri is also the term sometimes used for the town of Mempawah.
} 


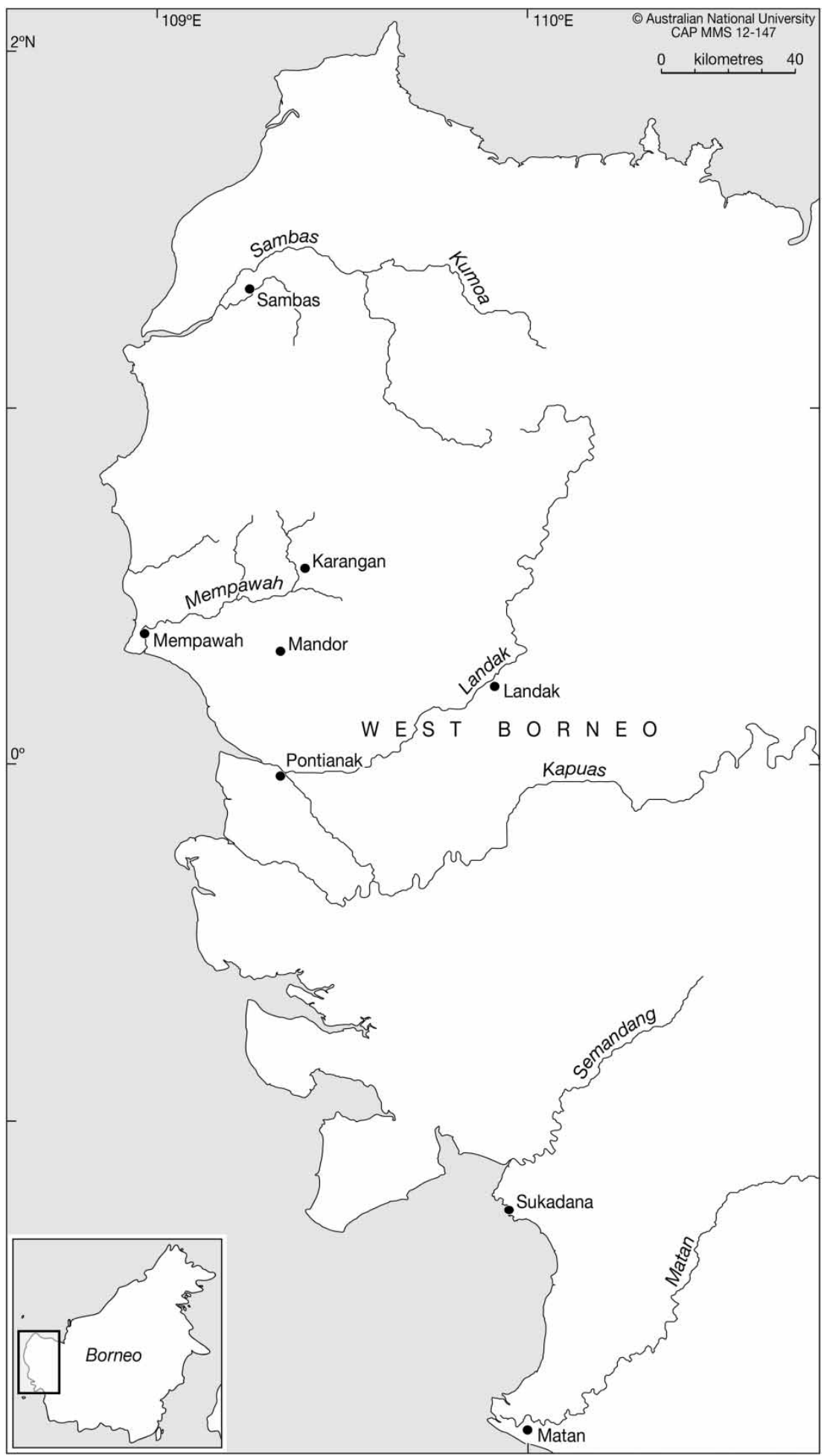

FIGURE 1. West Borneo at the end of the 18th century. 
were considerably reduced, through a combination of foreign intervention, competition from neighbouring states and divided internal leadership. Different sources: traditional Malay accounts, contemporary Malay letters, local and metropolitan Dutch accounts and post-Independence Indonesian histories, are examined, and these diverse sources reveal a variety of interpretations depending on the location, affiliation and era of the writer.

Through this comparative analysis, the general picture emerges of Mempawah as another example of a vulnerable Malay state struggling to retain its status in a volatile period in the history of the Malay Archipelago. It faced challenges similar to those of other states, including a division within the realm. While several recent works on the general history of the area (Heidhues 1998: 284; van Goor 1986: 100) have touched on the internal conflict, they leave the impression that the reduction in the power of the ruling family of Mempawah took place rapidly, within a couple of years. A closer examination of contemporary sources, several of which have not been examined before, suggests that resistance continued for at least two decades. The traditional ruling dynasty thwarted the usurpers, at least to some extent, well into the 19th century.

Mempawah grew out of a number of smaller polities, believed to be Dyak in origin, which existed along the interior tributaries of the Mempawah river. As the realm grew, the Malay-Bugis court became more sophisticated, exemplified in the composition of a royal Malay chronicle based on the achievements of Opu Daeng Menambun. ${ }^{2}$ The ruler had the title of Panembahan. In addition to Malay, Dyak and Bugis elements, the society of Mempawah, as with other Malay courts, came to have also a significant Arab influence. Sayid Syarif Husain ibn Ahmad al-Kadri, a noted religious scholar from Hadramaut (Yemen), had come to Borneo in about 1731, settling first in Matan, near Sukadana (van Goor 1986: 93; Willer 1855: 517). ${ }^{3}$ Later, in 1749, he moved to Si Bukit, the capital of Mempawah (Figure 2), at the urging of the then ruler, Panembahan Adi Jaya Kesuma, the son of Opu Daeng Manembun, and there rose to the position of Tuan Besar. ${ }^{4}$ Reflecting the increasing Arab influence, at the initiative of Sayid Syarif Husain, the seat of power was moved further downstream to an island in the Mempawah river called Trusan, which became the capital, with the new settlement adopting the same name as the state as a whole, Mempawah (Willer 1855: 518).

Sayid Syarif Husain's presence added to Mempawah's reputation as a centre of Islamic scholarship, this distinction having already being obtained by the arrival of Syeikh Ali bin Faqih al-Fathani, another renowned Islamic scholar, who had been enticed from Patani by Opu Daeng Menambun (Abdullah 1982: 5-7). ${ }^{5}$ Adi Jaya studied Islam and Arabic, probably under Syeikh Ali bin Faqih al-Fathani.

\footnotetext{
${ }^{2}$ The text of the Hikayat Opu Daeng Menambun was published in Schulze (1991) from the original ms. in Leiden University Library, Cod.Or.1754. The chronicle is one of the interlinked indigenous histories of Malay courts. See below, and also Matheson (1971: 382).

${ }^{3}$ Similarly, in respect of Java in the 19th century, Michael Laffan (2003: 43) states: 'The Hadramis ... enjoyed a special place of honour among the Jawa by virtue of their assumed kinship with the family of the Prophet. This was emphasised by the use of such customary honuorifics as habib and sayyid.'

${ }^{4}$ Chief office-holder, chief minister.

${ }^{5}$ Based on accounts in Silsilah Melayu dan Bugis (Raja Ali al-Haji 1973).
} 


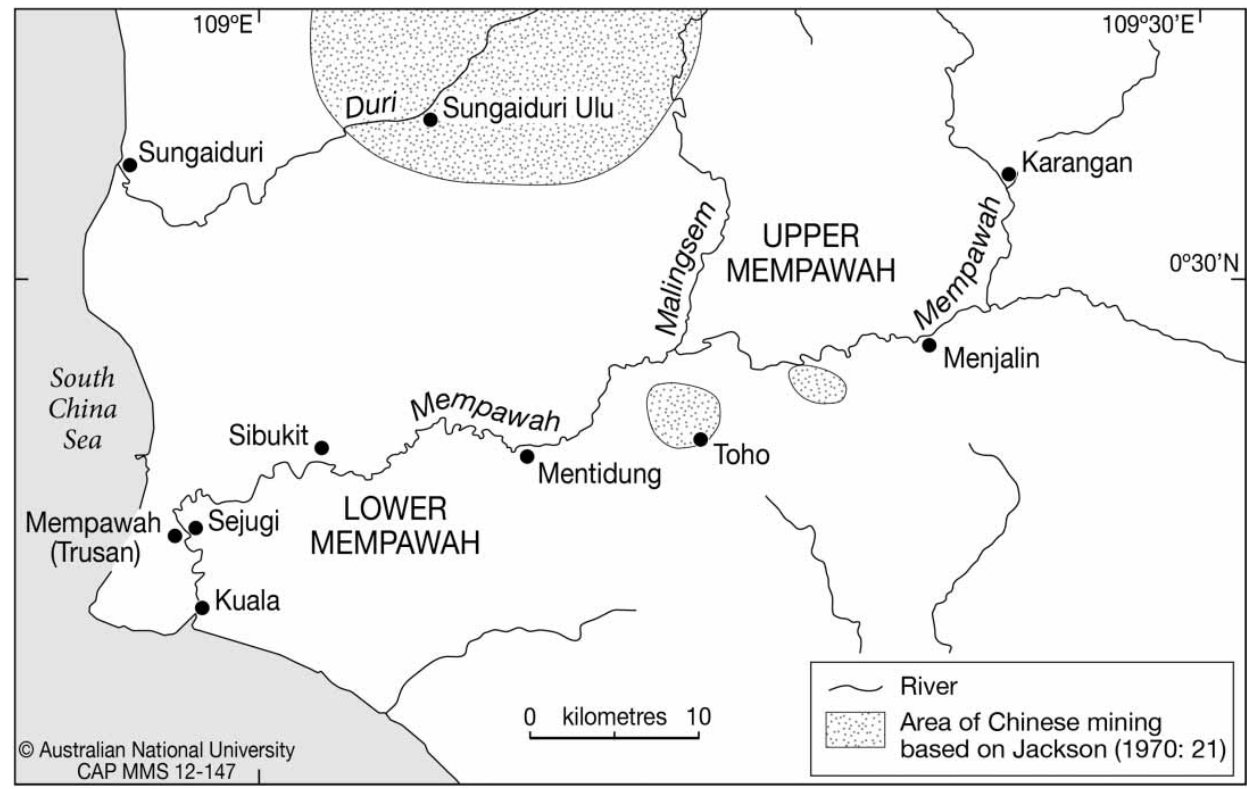

FIGURE 2. Upper and Lower Mempawah after 1787.

The new capital located at Trusan was close enough to the sea to be a port, but far enough inland to be protected against piracy. ${ }^{6}$ Mempawah flourished in the mid 18th century as a state based on trade from the catchment of the Mempawah river. The upstream people marketed forest products and agricultural goods in exchange for imported items, as was typical of other estuarine states of Borneo and other parts of the Malay Archipelago (Heidhues 1998: 275; van Goor 1986: 89-92: Willer 1855: 518). ${ }^{7}$ Exported items included gold, ${ }^{8}$ rice, diamonds, rattan, beeswax and sago which were exchanged for imported goods such as cloth, iron, textiles, salt, opium and tobacco. One report indicates that by 1786 as many as 500 vessels of all sorts called annually at Mempawah: junks and wangkang ${ }^{9}$ from China, padewakan from Sulawesi and European sailing ships (Willer 1855: 525). A contemporary English description said there were 'a great number of Chinese merchants settled here, and seldom less than four or five of their junks, which generally arrive in February or March', reiterating

\footnotetext{
${ }^{6}$ Marauding of coastal settlements was part of an increase in piratical activity at the end of the 18th century, the main factors for such an increase being the decline of the orang laut, an increase in the number of anak raja (princes), and the growing strength of the Ilanun, all taking place at a time of political flux with the decline of the Dutch East India Company (VOC) and an expanding China trade (Lopez 2010: 195).

${ }^{7}$ However, van Goor (1986: 94) argues Mempawah did not compare 'in splendour' with Banjarmasin during the 1760s and Mempawah never achieved the status of a sultanate in the 18th century. For a discussion of the hulu-hilir (upstream-downstream) characteristic of a Malay state see Bronson (1977). Specific examples of the hulu-hilir format as it existed in Palembang, Jambi and Siak are discussed in more detail in Kathirithamby-Wells (1993, 1997); B. Andaya (1997) and Barnard (2003). ${ }^{8}$ For the important role of the Chinese gold mines in west Borneo see Heidhues (2003).

${ }^{9}$ Wangkang was an ocean-going Chinese junk; padewakang a Bugis trading vessel.
} 
that Mempawah was 'one of the best markets to the eastward for opium' (Milburn 1813: 418). ${ }^{10}$

For the Dutch, the western part of Borneo was of little concern and remained outside of their sphere of influence until 1778 (van Goor 1986: 86). Landak and Sukadana, two states respectively west and south of Mempawah, were previously claimed by the Sultan of Banten, but in that year he surrendered his right to those areas to the VOC and the Dutch became more closely involved with western Borneo. The Dutch were motivated principally by three reasons: the need to obtain new sources for the purchase of gold, a rising fear that other European powers might seek to exert an influence or even settle on areas of the archipelago over which they, the Dutch, did not have a strong influence, and a desire to restrict Bugis influence.

At this time, Sayid Syarif Husain's son, Pangeran Sayid Syarif Yusuf al-Kadri, better known as Sultan Syarif Abd al-Rahman of Pontianak, began to play an important role in the politics of Mempawah. One of his wives was a sister of the Panembahan (Figure 3). He had grown up in Mempawah, spent seven years roaming the archipelago, returning briefly to Mempawah, only to find that his ambition and strong temperament, as revealed by subsequent events, made him unwelcome. He departed again and founded the settlement of Pontianak (Heidhues 1998: 280). He was crowned sultan and became a power in the region. It was therefore with Pontianak that the Dutch decided to sign an agreement and where they established a post in 1779. Abd alRahman was prepared to accept the VOC's trade monopoly over products from the interior, the most profitable of which it anticipated would be gold and diamonds, in return for which he received a percentage of the proceeds (Jacobs 2006: 175-6). While he recognised Dutch sovereignty, he benefited from their acknowledgement of him as sultan, for this recognition further enhanced his prestige in the region.

Mempawah's misfortunes began in 1785-86 when the comparative newcomer, Pontianak, together with the Dutch, commenced campaigns to eliminate nearby rival centres of power on the coast, Sukadana and Mempawah. After razing Sukadana and forcing the ruling family to flee to Matan, a combined Pontianak and Dutch force blockaded Mempawah. The Dutch squadron consisted of four Dutch naval vessels and a VOC ship with a total of 144 guns and a force of over 800 men. Led by Commander W. Silvester the fleet anchored off Mempawah on 28 April 1786 (Willer 1855: 5345). ${ }^{12}$ Silvester's orders were to occupy Mempawah, drive out the Riau Bugis who were there following the Dutch attack on their stronghold on Riau, and to displace the ruling Panembahan with the son of Abd al-Rahman, Syarif Kassim. ${ }^{13}$ Because of its geographical location, Silvester and Abd al-Rahman were not able to conquer Mempawah immediately; the river had too shallow a draught for the Dutch vessels and the town was out of range of the ships' cannon. Negotiations commenced between the two sides. On 3 May, Adi Jaya communicated that he was prepared to cede half of his land

\footnotetext{
${ }^{10}$ The vibrant opium market is indicative of the growing trade by the English traders from India.

${ }^{11}$ For Dutch-Bugis rivalry and the international context of this 'forward movement' by the Dutch see Jacobs (2006: 173-4, 292); Lewis (1995: 113-22).

${ }^{12}$ Veth (1854: 275) says it was 1787 , a date accepted by several writers.

${ }^{13}$ Ibid. Adi Jaya was an uncle of Syarif Kassim. Adi Jaya's sister had married Syarif Abd al-Rahman. Thus Syarif Kassim and Nata Kesuma, see below, were cousins.
} 


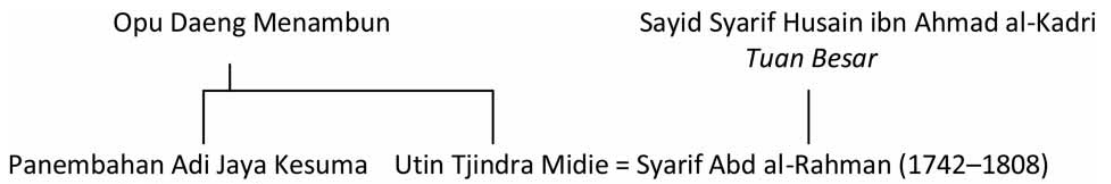

(1715-1790)
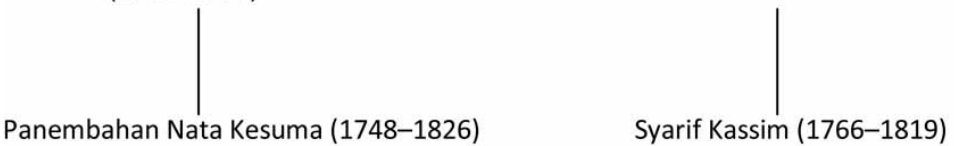

FIGURE 3. Simplified genealogy of Mempawah, showing relationships between leading participants in the events of 1787-1808 (based on Willer 1855, 1857).

and half of his revenue to the VOC provided he received a guarantee that he and his descendents would continue as rulers. This, Silvester was unwilling to accede to, and negotiations interspersed by minor skirmishes continued. Finally, on 23 May, the attacking forces occupied the capital, only to find that the Panembahan and his retinue had withdrawn up river.

On 21 June, Syarif Kassim was installed as Panembahan and signed a heavily burdensome agreement with the VOC (Willer 1855: 540-1). ${ }^{14}$ As a vassal his independence was curtailed; among other stipulations, he could not construct any forts, communicate with foreign powers or appoint or dismiss chiefs without informing the Dutch Resident in Pontianak. Regulations regarding the income to be paid to the VOC were also demanding and if broken, the ownership of the realm would revert to the Company. Willer makes the point that Abd al-Rahman and Syarif Kassim agreed to these harsh conditions because they knew that later on the Dutch would be in no position to enforce them. On 27 June the Dutch fleet departed leaving one station commander and 15 soldiers to maintain a Dutch presence (Willer 1855: 541, 543). Notwithstanding the occupation of the capital, Syarif Kassim commanded only the territory around Trusan and the coastal areas. The largest part of the realm was still loyal to Adi Jaya. At first, the traditional ruler moved his seat of authority between various settlements in the hinterland but finally settled at Karangan. The situation of a divided state continued for the next 21 years.

In 1788 the Dutch recommenced negotiations with Adi Jaya. Through the Dutch Resident of Pontianak, Jacob Klaagman, these continued until 1790, Adi Jaya and Klaagman even meeting at Si Kantjor in October 1789. But the negotiations were unsuccessful (Willer 1855: 544-5). Abd al-Rahman and Kassim were so determined to crush the ruling Panembahan that, independent of the Dutch, they dispatched a fleet against several of the upstream settlements in December 1789, but their campaign did not achieve its purpose of forcing trade on the river to be reopened (Willer 1855: 550).

Adi Jaya died at Karangan on 1 August 1790 at the age of 75. Early in his life he had visited Batavia and had been courted by the Governor-General as a future leader and his marriage in that Dutch city in the 1740 s is described in traditional Malay histories as an

\footnotetext{
${ }^{14}$ I have not seen a text of this agreement, which is not included in Corpus Diplomaticum NeerlandoIndicum, but a summary is provided by Willer.
} 
occasion of great celebration. ${ }^{15}$ Despite these early close associations with the Dutch, in local tradition he is hailed as their inveterate opponent. On his death, the rule of Upper Mempawah was at first shared between Adi Jaya's widow, his brother and a son, but by 1795, that son, Nata Kesuma, who had been one of the Regents, was sole ruler of the area (Willer 1855: 552-4). ${ }^{16}$ The Dutch withdrew their post at Mempawah in 1791 due to a failure to make any progress politically and a lack of profitability in trade (Willer 1855: 553), but the division in the realm continued.

Sayid Kassim commenced tentative communications with Nata Kesuma in 1792, which were not altogether rejected despite the fact that the old ruling house of Mempawah refused to have anything to do with Abd al-Rahman himself. Another son of Adi Jaya had been sent to Batavia to intercede with the VOC on behalf of Mempawah against the Sultan of Pontianak. During 1795 communications between Panembahan Nata Kesuma and the Dutch recommenced, though the Dutch did not recognise the ruler of Upper Mempawah's title (Willer 1855: 555). The division in the realm meant things continued to be difficult for Kassim as well, which probably accounts for his murder of the English country trader, Captain Thomas Sadler, in July 1795, to whom he was in debt (Miller 2012: 63-84).

In early 1796 Nata Kesuma, while continuing his rule over the interior Dyak areas, moved his capital from Karangan to a settlement at the mouth of the Sungei Duri with the approval of the ruler of Sambas. But the stalemate with his cousin Sayid Kassim continued, the former ruling Upper Mempawah, the latter, Lower Mempawah. At this time, Kassim appears to have conceded to his cousin that he would, eventually, return Lower Mempawah to Nata Kesuma, knowing that he himself had been anointed to succeed his father as Sultan of Pontianak, but admitted that he could not do this while Abd al-Rahman was alive. This situation continued for a further two years, until in 1798 Kassim invited Nata Kesuma to return and reside at the capital, which he did, settling at Sejugi, about a mile from Trusan (Willer 1855: 556). The state remained administratively divided; Nata Kesuma continued to be responsible for managing Upper Mempawah with Kassim continuing to govern Lower Mempawah. Meanwhile, the personal reconciliation between the two cousins was further confirmed when one of Kassim's sons married a daughter of Nata Kesuma.

When Abd al-Rahman died in 1808, he was succeeded in Pontianak by Kassim who returned the area of Lower Mempawah to Nata Kesuma and the Malay-Bugis ruling house of Opu Daeng Menambun. However, for Mempawah, the years of division initiated by the attack of the Dutch squadron had proved disastrous in the long term. The trade and the territory had been much diminished during the two decades of warfare and disunity. Despite strong resistance, Mempawah was never to regain its position as a major port. The allies of the 1786 campaign had reason to celebrate: the Dutch had eliminated the threat of Bugis power and prevented any possible English

\footnotetext{
${ }^{15}$ See, for example, in the Hikayat Opu Daeng Menambun (Schulze 1991: 64-7) and in the Tuhfat alNafis (Raja Ali Haji ibn Ahmad 1982: 70-5). The fact that Adi Jaya had visited Batavia, met the Governor-General and presumably other Dutchmen, is difficult to reconcile with van Goor's statement, based on the rather erratic Dutch Resident Kloek's report, that Adi Jaya had met only his second Dutchman in 1778 (van Goor 1986: 94).

${ }^{16}$ Nata Kesuma was also known as Gusti Jati and Pangeran Anom, though officially when ruler, as Panembahan Nata Kesuma. This 'Pangeran Anom' of Mempawah is not to be confused with the notorious Pangeran Anom of Sambas, about whom, see Smith (2007).
} 
encroachment, while Pontianak had usurped Mempawah as the leading centre of trade on the southwest coast of Borneo (Heidhues 1998: 276, 284-5; Lopez 2010: 201-2).

\section{Traditional Malay accounts}

Three traditional Malay histories, Silsilah Melayu dan Bugis, Hikayat Opu Daeng Menambon and Tuhfat al-Nafis, while they do not relate the actual events which took place in Mempawah during the years of its division and decline, nevertheless provide a Malay perspective on related circumstances leading up to that time (Braginsky 2004: 352; Raja Ali alHaji 1926, 1973; Raja Ali Haji ibn Ahmad 1982; Schulze 1991). It has already been mentioned how these works narrate Adi Jaya's celebrated visit to Batavia sometime between 1743 and 1750 when Gustaaf W. van Imhoff was Governor-General (Hall 1955: 749). They do not contain precise chronological details, ${ }^{17}$ but they show, for example, that Adi Jaya was, from a young age, familiar with the upper reaches of the Mempawah realm; he traded there after his return from Batavia, was invited to marry one of the chiefs' daughters, and was involved with suppressing rebellious sections of the population (Schulze 1991: 69, 70-1, 73). These early experiences help to explain his ability to consolidate his authority in Upper Mempawah after 1787.

The works are valuable for the information they provide on the strength of the Bugis influence in the court, an important factor among the reasons for the Dutch taking the actions they did. The three Malay histories reflect the Bugis point of view and while predominantly concerned with events in Riau, they are also valuable in respect of Mempawah. As Braginsky (2004: 382) has noted, these histories also strive 'to represent this [Bugis] history in all its links with the events that took place in neighbouring countries'. Indeed, it has been suggested that Mempawah may have been the place of origin of Hikayat Opu Daeng Menambon, it having been written initially in Buginese by Opu Daeng Menambun himself, one of the five famous Bugis brothers (Raja Ali al-Haji 1926: 350-1; Schulze 1991: 36), and then translated into Malay by his son, Panembahan Adi Jaya. It is further hypothesised that Raja Ali Haji, the 19th-century author of the Tuhfat al-Nafis and the Silsilah Melayu dan Bugis, compiled his two later works from this original work (L. Andaya 1975: 8, 18, 19, notes 16, 20). Besides revealing the strength of Bugis influence, they also confirm the sophistication of the Malay court at Mempawah. In one episode, the ability of Adi Jaya to read Arabic and recite and understand the Koran is clearly explained, enhancing his position as ruler in the eyes of many of the chiefs (Raja Ali Haji ibn Ahmad 1982: 72-3; Schulze 1991: 70). Ironically, it is the strong Bugis influence in the Mempawah court, so proudly depicted in these traditional Malay works, which was one of the reasons for the enmity of the Dutch and consequently the eventual decline of the state.

\section{The perspective of T.J. Willer}

During the 19th century the European perspective on the history of Mempawah was based largely on the detailed writings of the experienced Dutch official, Thomas

\footnotetext{
${ }^{17}$ See Matheson and Andaya's remarks in Raja Ali Haji ibn Ahmad (1982: 5-6).
} 
Josephus Willer. ${ }^{18}$ Willer served in the Netherlands East Indies between 1832 and 1855 and had postings in Java, West Sumatra, North Sumatra and in eastern Indonesia, before he served in Borneo. His detailed reports on the peoples and societies of the areas over whom he exercised administrative responsibility were highly regarded. ${ }^{19}$ He was the Resident of West Borneo towards the end of his period of service, between early $1850^{20}$ and November 1853. This was a time of serious political disruption as a result of fighting in the Chinese mining areas (Heidhues 2003: 85-125) and Willer fell out of favour with the central Dutch administration in Batavia because of his unconventional attempt to bring about peace. Willer's approach was sympathetic to the Daoist beliefs of the Chinese and he chose to adopt the practice of burning the seal of a particular kongsi (clan) in order to reach a settlement. The Governor-General was appalled by such an acknowledgement of 'mysticism' and Willer was demoted to inactive status sometime early in 1853 (Heidhues 2003: 95). But by November of that year he had regained sufficient official approbation as to be appointed Resident of Riau. ${ }^{21}$ After Willer returned to the Netherlands in 1855 his extensive knowledge of the Malay world was highly valued and he continued to write and publish on the region. Among other appointments, he was made a member of the Royal Commission for Colonisation and a Board member of the Royal Institute for Linguistics and Anthropology. ${ }^{22}$

It is most probable that it was when he was suspended from his official duties during 1853 that Willer compiled the detailed local histories of Mempawah and Pontianak. He wrote a chronology of events using a mixture of official Dutch reports and local tradition. He also compiled sophisticated genealogies of the ruling families of Mempawah and Pontianak which he says he did through discussions with the ruling Sultan of Pontianak (Willer 1855-1857). Willer's history of Mempawah, published in 1855, caused the prominent Dutch historian P.J. Veth (see below) to revise his own monumental work on West Borneo in respect of the history of Mempawah and Pontianak (Veth 1856: ii).

Willer naturally has a Dutch perspective on events; he talks in such terms as 'our ships' and 'the shells did not reach us', and he provides more details of Dutch casualties than those of other forces (Willer 1855: 538, 541). However, he is not uncritical of the actions of the VOC. He is particularly judgmental regarding the Dutch decision to support Abd al-Rahman over what he, Willer, considered the traditional, legitimate ruling house of Mempawah. Willer's view was that when Panembahan Adi Jaya sent his son as an envoy to Java to seek the support of the Dutch against Pontianak in 1785, the Dutch chose to ignore him, agreeing on the other hand to the request from Abd al-Rahman to attack Mempawah. The Company, Willer wrote, listened to the argument of an 'Arab pirate' (Arabischen roover) rather than provide friendship and

\footnotetext{
${ }^{18}$ See the entry 'Willer (Thomas Josephus)' in Encyclopaedie van Nederlandsch- Indie 1917-1939, vol. 4: 784-5.

${ }^{19}$ For example, part of an article on the Batak people originally published in the Tijdschrift voor Neerlands Indie 8 (1846) was translated into English and published in the Journal of the Indian Archipelago and Eastern Asia in 1849 as 'The Battas of Mandheling and Pertibi'.

${ }^{20}$ Heidhues (2003: 85) states that he arrived in West Borneo as the new Resident in February 1850 whereas in the Encyclopaedie van Nederlandsch-Indie (1917-1939) Willer's appointment was in April of that year.

${ }^{21}$ Encyclopaedie van Nederlandsch-Indie 1917-1939, vol. 4: 784.

${ }^{22}$ Ibid.
} 
allegiance to the embassy of a ruling house which had a tradition of 14 generations of history behind it. ${ }^{23}$

The Dutch attacked Sukadana because their Bugis enemy, Raja Ali, was residing there (Willer 1855: 533). Another reason for the Dutch attack on Sukadana and Mempawah was the Bugis diversion of trade away from Pontianak after the Dutch established a post there, the position of the Dutch complimenting that of Pontianak in its own growing trade rivalry with Mempawah (Jacobs 2006: 176). According to Willer, Syarif Kassim went to Batavia after the defeat of Sukadana to persuade the Dutch to attack Mempawah where he said Raja Ali and his Bugis followers were then sheltering (Willer 1855: 533-4). Abd al-Rahman may also have been furious with Mempawah over the non-repayment of a debt Mempawah had incurred during a dispute with Sambas. ${ }^{24}$

Willer further emphasised Abd al-Rahman's untrustworthy character in his description of the campaign, where Silvester was left to blunder about through lack of knowledge of the terrain, information that could have been supplied by Abd al-Rahman (Willer 1855: 536). Willer also points out that while Adi Jaya conceded that Raja Ali and his Riau Bugis followers, the enemies of the Dutch, were in Mempawah, he, Adi Jaya, claimed that he had ceased providing for the Bugis (Willer 1855: 534). Willer is sympathetic to Adi Jaya's position, in that he did not have the forces, made up of Dyak and coastal Malays, to actually drive the Bugis from his realm. Willer concludes that the Dutch, while they had the benefit of a European fleet in the area, seized the opportunity to attack Raja Ali and support their chosen ally Abd al-Rahman by attacking Mempawah and making his son the ruler.

As noted earlier, Willer points out that Adi Jaya was prepared to compromise during the siege of Mempawah, being willing to cede half of the state's revenue to the VOC provided he received a guarantee that he and his descendents would remain as rulers (Willer 1855: 537). Silvester was unable to agree to this as it contravened his instructions. During further negotiations, Adi Jaya was even prepared to cede the immediate area around Trusan to the VOC (Willer 1855: 538). During the period when Adi Jaya controlled the interior and Sayid Kassim held the capital only with the support of the Dutch and Pontianak, Willer maintains that the Dutch Resident at Pontianak, Jacob Klaagman, was simply a puppet in the hands of the wily and boastful Abd al-Rahman (Willer 1855: 543). He blames Abd al-Rahman for inciting the Chinese in Mandor to rebel against Adi Jaya (Heidhues 1998: 288, 2003: 103; Willer 1855: 544), which diverted trade away from Mempawah and through Pontianak, though it weakened Kassim's position at Trusan as well.

While Klaagman attempted to negotiate a settlement with Adi Jaya in 1788 and 1789, Willer blames the 'al-Kadrie', that is, Abd al-Rahman and Sayid Kassim, for Klaagman's complicity in the military expedition up river in December 1789 to try and force Adi Jaya to open up the river traffic (Willer 1855: 550-1), though the Dutch did not actually participate in the expedition. Aware of the expedition, Klaagman did not report the action to his superiors until a year later. As has been shown, the expedition failed, and Batavia later blamed lack of progress in negotiations with Adi Jaya on this onberadene (rash) and ill-advised military campaign. An agreement with

\footnotetext{
${ }^{23}$ Willer (1855: 534): Lopez (2010: 202, 216 note 66); Heidhues (1998: 285).

${ }^{24}$ Raja Ali Haji ibn Ahmad 1982: 376, folio 266, note 2.
} 
Adi Jaya continued to escape Klaagman and at the end of 1789, Willer says the al-Kadrie were still bursting with spite and jealousy, the Mempawah dynasty was still defending itself in the interior, and Klaagman was angry at the failure of his plans for reconciliation (Willer 1855: 548). The trade through Mempawah continued to decline while that through Pontianak increased.

Finally, Willer points out that Nata Kesuma continued to correspond with Sayid Kassim and with the VOC after the Dutch withdrew from Mempawah and Pontianak in 1791 but, like his father, remained adamant that Mempawah would not be subservient to Abd al-Rahman. It was only in 1798, when, as has been shown, Nata Kesuma was invited by Sayid Kassim to return to Trusan and share the administration of the state (Willer 1855: 556) that a form of reconciliation came about. It can be concluded therefore that Willer, through his highly critical comments on the characters of both Abd alRahman and Sayid Kassim and his anti-Kadrie interpretation of events, places far more responsibility for the decline of Mempawah on these two personalities than on the Dutch. Nevertheless, the Dutch are not blameless, for they had been duped and manipulated by the al-Kadrie. Willer is far more sympathetic to the historic claims of the ruling family and has an understanding of the intolerable position in which they were placed.

\section{The perspective of P.J. Veth}

Another early Dutch work which covers the events surrounding the decline of Mempawah was that by Pieter Johannes Veth, one of the most highly regarded Dutch scholars of the Netherlands East Indies during the 19th century. After early study of the Middle East and in theology he taught English and Malay at the Military Academy in Breda in 1838, and after a period in Amsterdam moved to Leiden in 1864, writing and lecturing on politics, geography, anthropology, history, natural history and educational systems. ${ }^{25}$ In addition to his prodigious scholarly output, he was a political activist and one of the foremost intellectuals of the liberal movement against the prevailing Cultivation System in the Netherlands Indies. His first detailed work on the Indies was his twovolume work on West Borneo, Borneo's Wester-afdeeling: Geographisch, Statistisch, Historisch ... (1854-1856). Between the publication of the first and second volumes, Willer's work had been published. Veth, who was based in the Netherlands and never went to the Indies, was thus reliant on sources available in the home country. He was sufficiently enlightened and magnanimous to write in his second volume:

I very much regret that this important work [i.e. Willer's] not only appeared too late for me to make use of it in my first volume, but it also came into my hands when volume 2 was already largely in draft form. Many details on the history of Mempawah and Pontianak, especially relating to the chronology of events and the genealogy, are much better and more correctly investigated by the local writer than are ascertained in this (my current) work. ${ }^{26}$

\footnotetext{
${ }^{25}$ Van de Velde (2006); Fasseur (1993: 80); Encyclopaedie van Nederlandsch-Indie 1917-1939, vol. 4: 567.

${ }^{26}$ Veth (1856: 466 note). Veth (1856: ii) also wrote that Willer's work had 'brought to light many inaccuracies I made in my account of the foundation of Pontianak (in volume 1)'. My translation.
} 
Veth's work is wider in scope than Willer's, as indicated by the title, covering additional subjects to those relating to the history of the rulers of Mempawah. Nevertheless, in the parts where he concentrates on the Dutch and Pontianak attack on Mempawah, he is less critical of Abd al-Rahman than Willer and not as sympathetic to the current Panembahan and the Malay-Bugis ruling family. Veth gives as one reason for the Dutch attack, a fear of the English occupying Borneo, and he also accepts the rumour that an English person had advised Mempawah on how to strengthen its defences (Veth 1854: 275). Like Willer, he writes from a Dutch perspective, but he is brutally realistic about the fact that 'Mempawah never recovered from the blow that the VOC and Abd al-Rahman inflicted on it' (Veth 1854: 87, 278; my translation). He concedes that much of the trade transferred to Pontianak and that Mempawah was condemned to insignificance as a result of the attack. Its former importance as a place for trade had been all but lost.

While this was to prove correct in the long term, Veth is too perfunctory in his dismissal of Adi Jaya's and Nata Kesuma's resistance. He wrote in volume one, for example, that Adi Jaya died soon after his flight into the interior and that it was Syarif Kassim that 'allowed' Adi Jaya's son, Nata Kesuma to return to the capital. ${ }^{27}$ As we have seen, it was not until four years had passed following the Dutch and Pontianak attack that Adi Jaya died, and it was another eight years before Nata Kesuma agreed to accept Syarif Kassim's offer to return to the capital and to rule the divided realm jointly. Veth places greater emphasis for the decline of Mempawah on Nata Kesuma being a physically and intellectually weak ruler. Even though conceding that Nata Kesuma may have controlled a part of the interior, Veth describes him as being completely under the influence of Sayid Kassim. He continues to hold this view in volume two of his work, despite the publication of Willer's history and he paints a damning pen portrait of Nata Kesuma when describing the Panembahan's behaviour following the return of the Dutch after the British interregnum between 1811 and 1816 (Veth 1856: 14, 206, 466). According to Veth, Nata Kesuma was completely prepared to hand all power to the Dutch provided he could remain living at the capital. It could be argued that Nata Kesuma was by that time simply pragmatic enough to accept the overlordship of the Dutch under similar conditions accepted by Abd al- Rahman and Sayid Kassim. The Dutch raised Nata Kesuma's nominal status in 1822, granting him the title of Sultan of Mempawah, in which position he ruled until his death in 1826 (Veth 1856: 14, 466; Willer 1857: 70).

Veth was a strong advocate of the liberal attitudes and reforming policies of the Netherlands, and believed that, as he said, 'national honour and national duty required that the Dutch try to raise up the lot of the natives'. ${ }^{28}$ Nevertheless, compared to Willer, his work on Mempawah has a far less sympathetic ring to it and because of his metropolitan perspective and lack of experience in the Indies, is more distant and detached from local events.

\footnotetext{
${ }^{27}$ Veth (1854: 279): De gewezen Panembahan van Mampawa stierf niet lang na zijne vlugt in de binnenlanden, en Sjerief Kasim vergunde aan zijn zoon Goesti Djati [i.e. Nata Kesuma] om naar de hoofdplaats terug te keeren ... (The former Panembahan of Mempawah died not long after his flight into the interior and Syarif Kassim permitted his son, Goesti Djati, to return to the capital.)

${ }^{28}$ Quoted in Fasseur (1993: 222); my translation.
} 


\section{Contemporary Malay letters}

A number of contemporary Malay letters exists which throw light on the events in Mempawah during the years of its resistance. ${ }^{29}$ Three have been examined for this article. ${ }^{30}$ For example, Sayid Kassim wrote a revealing and idiosyncratic letter to the Governor-General on 17 November 1789 (Figure 4) in which he pointed out the difficulties he was having in bringing Adi Jaya to heel and ensuring an improved flow of goods down the river, which the Governor-General had requested he attempt to achieve in earlier correspondence:

... the wise advice of the Governor-General and Members of the Council of the Indies, exhorting me to reach a settled situation in the interior in order to facilitate the products of the villages of Mempawah to be sent downstream. ${ }^{31}$

Clearly Kassim was under some pressure given the realm was in a divided state. He insisted he had made every attempt to ensure that the raja-raja of the interior followed the orders of the Company, but he had to concede that he had failed. According to him, it was all Adi Jaya's fault. Not only had Adi Jaya fled to the interior, he had broken a promise to call all the raja-raja to meet with the Resident and, claiming he was sick, he had prevaricated after agreeing to enter into discussions with Klaagman. When Adi Jaya and Klaagman finally did have a meeting at Mentidung, Adi Jaya would not accept the Resident's advice:

... when the Resident met with Panembahan Adi Jaya Kesuma, Adi Jaya went back on his word, and did not want to accept advice. This I don't understand. I trust Your Excellency and Members of the Council of the Indies will understand the situation.

\footnotetext{
${ }^{29}$ There appear to be in existence 19 Malay letters from west Borneo covering the years under consideration in Leiden University Library. Not all relate to Mempawah. Most were written by Syarif Kassim or Abd al-Rahman, though one was written by Adi Jaya, one by the chiefs of Mempawah, one by Adi Kesuma and one by Pangeran Anom Kesuma. All were addressed to the GovernorGeneral in Batavia. To my knowledge only three have been published; two written by Abd alRahman in 1806 and 1807 respectively which are unrelated to events in Mempawah, and one by Syarif Kassim in 1808 informing the Governor-General of the death of Abd Al-Rahman and his own ascension to the Sultanate. These three published letters are in Meursinge (1847: 5-12). All 19 letters are described in Wieringa (1998); the three letters discussed here are described on p. 337. ${ }^{30}$ The three from Mempawah have been selected because they are directly concerned with the events under consideration and as they represent a cross-section of opinion; one is from Sayid Kassim, one from Panembahan Adi Jaya and one is from a group of chiefs. I hope to publish and discuss all of the letters of Sayid Kassim in a later article.

${ }^{31}$ Leiden University Library, Cod. Or. 2239 I 2a. ... budinya sahifah Tuan Paduka Gurendur Jendral dan Tuan-tuan Raden Pan India menghendakikan Panembahan akan mencari kesenangan tanah ulu supaya berhimpun membawa hilir hasil-hasil desa negeri Mempawah.

32 ... Petor Besar bertemu dengan Panembahan, Adi Jaya Kesuma mungkir dari katanya tiada mau mendengar nasihat-nasihat. Inilah Panembahan Syarif Kassim sudah tiada mendapat akal. Terlebih maklum Tuan Paduka Gurendur Jendral dan Tuan-tuan Raden pan India.
} 


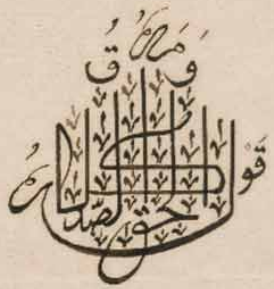

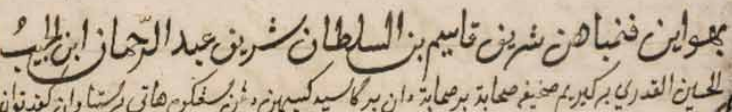

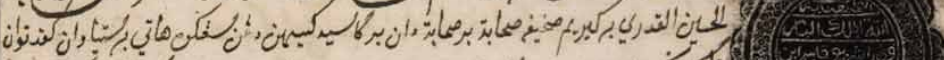

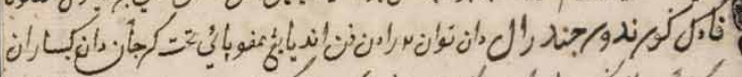

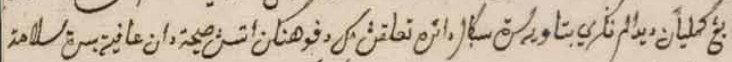

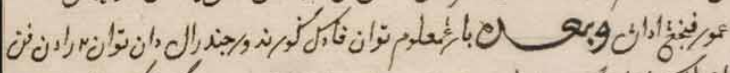

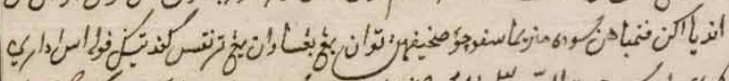
ن

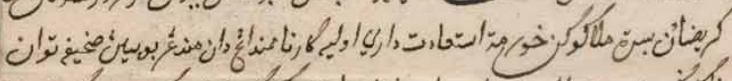

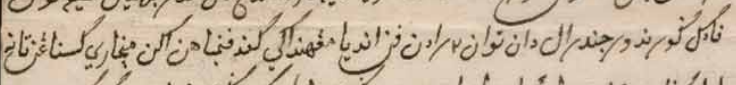

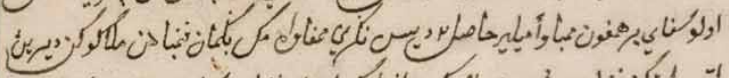

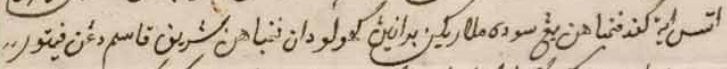

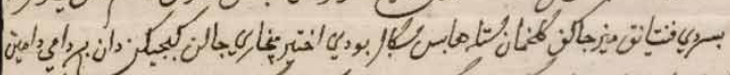

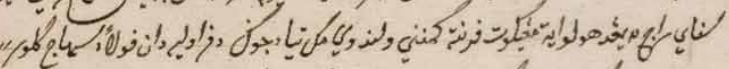

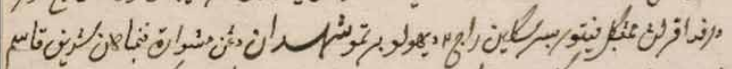

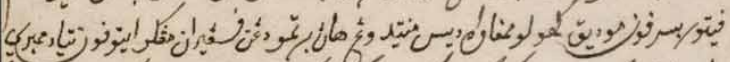

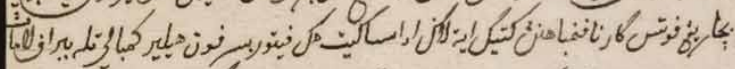

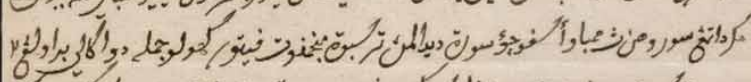

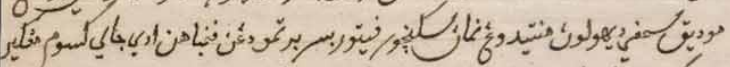

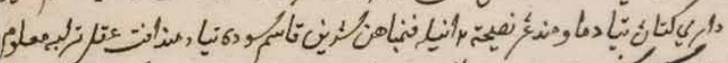

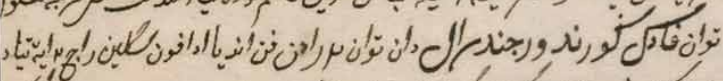

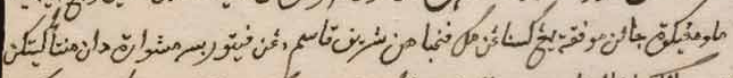
ol

FIGURE 4. Letter from Sayid Kassim to the Governor-General in Batavia dated 17 November 1789. Original in Leiden University Library, Leiden Cod.Or. 2239 I 2a.

He said he could not get the chiefs to accept him as leader and even claimed that Klaagman had to return downstream quickly when he was threatened with violence. This letter was written just the month before Kassim launched the attack, probably approved by Klaagman, as has been shown, an action which was later 
criticised by the Dutch government in Batavia as being unhelpful in ameliorating the situation.

In his letter Kassim reveals himself as also being preoccupied with more material issues, and being concerned with acquiring items that might enhance his status. A significant portion of this otherwise political and diplomatic letter consists of a list of furnishings that Kassim requested or had received already from the Governor-General. This is in stark contrast to the more politically focused letter of Adi Jaya (see below):

Furthermore, Panembahan Syarif Kassim requests the favour of Your Excellency the Governor-General and Members of the Council of the Indies that they may bestow on us the following interior decorations; two pair of glass candlesticks and a pair of crystal-embellished glass lamps which are fitted with surrounding candlesticks. ${ }^{33}$

Kassim offered to pay for the items. He also expressed his gratitude in the letter for a large number of textiles that he had received from the Dutch. ${ }^{34}$ Cloth, as a form of currency, would have been valuable in retaining the loyalty of officials and followers. To reciprocate these gifts, Kassim sent with his letter 16 tahil $^{35}$ of gold dust, worth 32 ringgit in value. Overall, the letter reveals, in addition to a more sophisticated approach to diplomacy compared to that of Adi Jaya, Kassim's close relationship with the Dutch.

For his part, Adi Jaya wrote from Karangan to Batavia in late 1789, that is, during the period of negotiations with Jacob Klaagman. ${ }^{36}$ This letter is somewhat more informal and not as flowery and flattering in its salutations as is Kassim's, an indication of Adi Jaya's rather colder, not to say hostile, relations with the Dutch. In it Adi Jaya conceded that the situation was 'difficult living in the interior' (sangat mudarat di dalam hutan), but he showed the consistency of his political stand when he reiterated the position he had held since the attack by the Dutch and Pontianak forces in 1787; he was willing to negotiate with the Dutch, to concede a portion of the state's revenues to them and accept them as overlords. What he was not prepared to do was to transfer the title of ruler to Abd al-Rahman or any of the al-Kadrie:

Furthermore, we send this sincere letter to Your Excellency in Batavia because we have requested the Resident, Jacob Klaagman to come upstream as far as Sekancor in order that we may find a satisfactory way of discussing the situation ... Then we gave our reply to the Resident: we would be willing to reside under the government

33 .. Syahadan lagi Panembahan Syarif Kassim mohonkan atas keridaannya Tuan Paduka Gurendur Jendral dan Tuan-tuan Raden pan India boleh karuniakan perhiasan yang dipakai didalam rumah: dua pasang kandil gelas berinti, dan sepasang keristal karuniani pelita gelas yang dipasangkan dengan lilin berkeliling..

${ }^{34}$ These textiles consisted of a roll of gold morees cloth, thirty-six and half elo in length; two rolls of red velvet each fifty-two and a quarter elo in long, a roll of gold bafta from Surat, two rolls of green Surat silk patola, twenty-eight hasta in length, two further rolls of the same material seven hasta in length, two rolls of fine white Bengal cloth from Coromandel, six rolls of fine Cambay cloth from Coromandel, twenty-eight cubit in length, two rolls of Armenian unpatterned folded silk from Calicut and two rolls of second-type hand-cloth from Coromandel. An elo is a measure equal to 0.688 metres. Hasta is a linear measure equal to 45.72 centimetres.

${ }^{35}$ Tahil or thail is a weight used for gold of approximately 39 grams.

${ }^{36}$ Leiden University Library, Cod.Or. 2239 I 3. No date given. Received in Batavia, January 1790. 
of the Company, but we request that the Company agree to what we want ... If Your Excellency agrees to be our guardian under the Company authority, then let it be that there is no other ruler in the state and in the capital of Mempawah, other than the Company itself. Rather let it be that there is only one set of instructions coming from the Company to ourselves in the land of Mempawah. For better or for worse, let it be between just us and the Company. ${ }^{37}$

Adi Jaya may have been crafty in his manoeuvres with Klaagman as suggested by Kassim; playing for time here, waiting for a more advantageous position to negotiate there. But it has to be said that, in so far as his basic position was concerned, he remained constant and consistent throughout.

A third letter still extant from the time is that written by six community leaders in the Mempawah capital to the Governor-General and Council in Batavia, dated 20 November $1789 .^{38}$ In addition to the actual text, it includes Sayid Kassim's seal and that of five others. Three of these five seals are al-Kadrie's, the other two are seals of the Kapitan Bugis and the Kapitan Melayu. The writers refer back to the time of the attack on Mempawah and the agreement entered into at that time between Silvester and the local chiefs and confirm that the title of Panembahan had been confirmed on Syarif Kassim:

Furthermore, in addition we respectfully request Noble Sir, that a perusal be undertaken of the letter of tribute that was truly manifest by the representative of the Company, Mr Willem Silvester, during the time that Mempawah was suffering disturbances. At that time the representative anointed our chief with the title of Panembahan, which was followed by a treaty. ${ }^{39}$

The chiefs in the capital Mempawah confirmed that they continued to abide by the orders that Silvester had handed down, though they implied that this obedience was probably limited to those chiefs living in the capital: 'From the beginning we have received (and followed) until now the orders which were delivered by Mr. Willem Silvester but which in our view have only been adhered to by people in the capital. ${ }^{40}$

\footnotetext{
${ }^{37}$ Wabaadahu kemudian daripada itu maka adalah kita berkirim warkat al-ikhlas kepada tuan Besar di Betawi karena adalah kita sama Tuan Petor Besar Jakup Kalpman kita sudah panggil mudik hingga Sekancor, supaya boleh mencari jalan bicara yang baik .... Kemudian kita jawab sama Tuan Petor, suka kita duduk dibawah perintah Kompeni tetapi kita mintak sama Kompeni kita punya maksud di dalam hati ... Jikalau suka Tuan Besar pelihara sama kita serta dibawah perintah Kompeni, melainkan jangan ada raja yang lain memegang perintah daripada Kompeni didalam negeri atau didalam negeri Mempawah. Melainkan barang suatu perintah perkerjaan di dalam tanah Mempawah datang dari Kompeni kepada kita. Jikalau dapat baik atau jahat, kita sendiri dengan Kompeni.

${ }^{38}$ Leiden University Library, Cod. Or. 2239 I 4.

${ }^{39}$ Wabadahu adapun kemudian daripada puji-pujian yang memohonkan kepada Tuan Bangsawan agar supaya melihat dalam surat persembah yang kenyataan wakil dari Kompeni, Tuan Willem Silvester, tatkala masa sudah terganggu negeri Mempawah. Ketika itu wakil yang setiawan mangkat penghulu kami dengan gelar Panembahan, lalu menerima surat perjanjiannya.

${ }^{40}$ Maka dari mula-mula sudah diterima perintah yang diunjukkan oleh tuan Willem Silvester sampai waktu sekarang ini, yang kelihatan dengan pengelihat saya sekalian ini, hanya orang dalam negeri jua.
} 
Klaagman's predecessor, Walter Markus Stuart, (subsequently transferred to Sumanap on Madura), had said that there were 17 villages (or regions?) which had accepted the authority of the Mempawah capital, but the writers of the letter of 20 November 1789 were not prepared to say how many villages were under (Lower) Mempawah authority, nor state the number of traders who could reliably be said to be operating within the realm ruled by Sayid Kassim. ${ }^{41}$ There is therefore, a considerable element of doubt acknowledged by the authorities in Lower Mempawah about the extent of their control.

These three letters provide a contemporary Malay perspective on the situation. They confirm the divided nature of the realm and the limited extent of control exercised by Sayid Kassim outside of the capital Mempawah. Adi Jaya's willingness to negotiate with the Dutch, but not compromise with the al-Kadrie, is clearly demonstrated, while at the same time they show the different attitudes by the two parties towards the Dutch. In their style and appearance the letters also confirm the sophistication of the Mempawah Malay-Bugis court(s) despite the division in the realm and the state of hostilities. While they are plain in comparison with later richly illuminated letters of the Pontianak court, they are well written, especially the one by Kassim, and are attractive in appearance.

\section{Recent local histories}

Several recent local Indonesian histories of Mempawah and Pontianak give their own particular interpretation of the events under consideration here.

Upu Daeng Menambon Raja Mempawah dan Saudara-saudaranya, by Muhd. Shaghir Abdullah (1982) places greater stress on Adi Jaya's Islamic credentials, together with the strong Bugis connections. Its main source is the Silsilah Melayu dan Bugis and while it therefore does not cover the actual events between 1787 and 1808, it attempts to provide another side to Adi Jaya's character to account for his strong opposition to the Dutch. Adi Jaya's ability to read Arabic and his mastery of the Koran is given considerable emphasis to explain the religious nature of his fortitude in fighting to preserve the pre-existing nature of the realm (Abdullah 1982: 6-7). The author includes the description of the lavish wedding in Batavia of Adi Jaya and his first wife to confirm the strength of the Bugis network, though he is obliged to criticise the un-Islamic nature of such an ostentatious display of wealth. He exonerates Adi Jaya of guilt (Abdullah 1982: 27). ${ }^{42}$ He justifies Adi Jaya's actions in terms of his necessity as a guest in Batavia to agree to his Bugis grandfather-in-law's desire for an extravagant event and the obligation to

\footnotetext{
${ }^{41}$ Maka jumlah itu kedudukan orang berniaga yang sebenar-benar orang disana negeri ketaklukan Mempawah belum boleh dimahlumkan mengikut perintahan oleh penghulu yang ditetapkan. Maka sekalian sahaya ini mendengar kabar perkataan Petor yang dahulu sudah titahkan pulang duduk di Sumanap, ia itu, Walter Markus Stuart, mengatakan dibawah takluk Mempawah tujuh belas desa yang sudah tunduk mengikut perintah. Perkataan itu sahaya fahamkan dari pada Petor Besar di Pontianak. Demikian lagi seperti kata Meneer Stuart tujuh belas desa negeri itu, sekali-kali tiada. Maka sahaya sekalian belum mengetahui yang demikian adanya. Melainkan terlebih maklum Tuan Bangsawan.

${ }^{42}$ Barangkali didalam hatinya [Adi Jaya] tidak menyetujui perbuatan seperti itu karena beliau adalah seorang yang banyak mempelajari tentang hukum hukum Islam ... .
} 
fulfil the wishes of the Dutch Governor-General who supported it (Abdullah 1982: 278; Raja Ali al-Haji 1973: 180-4).

In contrast to Abdullah's book, which was published in Pontianak by an Islamic organisation, Ellyas Suryani Soren, a journalist who was born in Mempawah, provides a view that emphasises Mempawah's Dyak connections. In his Sejarah Mempawah Tempo Doeloe he is even less sympathetic to the Dutch (Soren 2003: 4, 58-64), for Adi Jaya's reign is described as one in which there was consistent opposition to the Dutch and which was also a period of great prosperity, a 'golden age' (masa keemasan). A colourful picture is painted of the variety of shipping, the exchange of goods and the communities of sailors and merchants from different parts of the archipelago clustered around Trusan, the island in the Mempawah river where the capital was located before 1787. Soren attests that the remnants of these communities remain in the contemporary Mempawah suburbs of Kampung Bugis, Kampung Banjar, Kampung Tambi, etc. According to Soren, in the year of the attack, Adi Jaya did not in fact retreat from the capital Mempawah, but, observing that the situation at the time was becoming difficult, merely shifted the seat of government of the realm to Karangan (Soren 2003: 4). ${ }^{43}$ There were, it is said, benefits for Adi Jaya resulting from such a move; additional groups of Dyak came to pay their respect because this was the first time they had actually set eyes on their ruler (Soren 2003: 60, 66). ${ }^{44}$

Contradicting Willer's interpretation, Soren (2003: 220) emphasises Adi Jaya's hatred of the Dutch (not the al-Kadrie) and, perhaps because of the author's long association with the public relations section of the provincial government in Pontianak, ${ }^{45}$ downplays the ruler's loathing for Abd al-Rahman. For Soren (2003: 62), it was only after Mempawah had repelled the first Dutch attacks that the Dutch persuaded Pontianak, through sweet talk and deceptive tactics, to join the invasion of Mempawah. Following a fierce battle upstream at Malinsam (Malingsem) in which there were many casualties, the Dutch accepted that there were large portions of Adi Jaya's territory that could not be occupied and that an era of Mempawah Hulu and Mempawah Hilir had begun.

In a local history account on the founding of Pontianak, Syarif Abdurrahman Alkadri, Perspektif Sejarah Berdirinya Kota Pontianak, it is also the Dutch that urge Pontianak to attack Mempawah (Rahman et al. 2000: 109). ${ }^{46}$ With the approval of the Dutch, Abd al-Rahman appoints his son Sayid Kassim to the position of Panembahan at Mempawah, but when Kassim signs the treaty with the Dutch, the authors consider this as an attempt by the Dutch to 'divide and rule', driving a wedge between Kassim and his father (Rahman et al. 2000: 110). The work is more judgmental of Kassim and is most critical regarding his rule in Pontianak, arguing that it was damaging to the ruling house. It accepts that he was involved in several murders, ${ }^{47}$ a judgment which could equally have been, but is not, applied to his father. In respect of the attack on

\footnotetext{
43 ... memindahkan pusat pemerintahan Kerajaan Mempawah di Karangan.

${ }^{44}$ Compare with accounts of Adi Jaya's earlier exploits in the interior in the classical Malay histories.

45 . . berkecimpung di Bagian Humas Pemda Tk.II Pontianak selama 27 tahun (active in the Public Relations section of the Pontianak Regional Government for 27 years).

46 ... Belanda mengajak Sultan Pontianak untuk menguasai Mempawah.

${ }^{47}$ Rahman et al. (2000: 112): . . terlibat dalam berbagai peristiwa pembunuhan. Ia bersikap keras terhadap lawannya dan diperintahkannya untuk dibunuh.
} 
Mempawah, it is clearly argued that, while it was done at the urging of the Dutch, it was undertaken in order for Abd al-Rahman to eliminate Mempawah as a centre of trade and to develop Pontianak in its place as a busy port and the centre of power over Western Kalimantan (Rahman et al. 2000: 91).

\section{Conclusion}

Through the fortitude of its leaders Adi Jaya and Nata Kesuma, Mempawah was, unlike Sukadana, able to resist the advance by the Dutch and Pontianak for two decades. A consistent opposition to the growing influence of the al-Kadrie was maintained and the traditional ruling house continued to control large sections of the interior. Fundamentally however, Abd al-Rahman's desire to form his own state and to eliminate commercial and political rivals, even when they may have been members of his own family, and the success of his actions in achieving these goals, proved to be the factor that had the most serious consequences for Mempawah. Its rulers were unable or unwilling to retain Abd al-Rahman within the realm and under their influence. Yet when he did act independently, they were able to resist his rival strategy for longer than he would have wished. By the time of Abd al-Rahman's death, the ruling family had not succumbed to the extent which he would have hoped for.

Nevertheless, by 1808, through the division of the realm and the diversion of trade, Mempawah had been subordinated as the major trading port on that part of the west coast of Borneo. Pontianak under the al-Kadrie had usurped its role as the leading commercial centre. Politically too, through a gradual submission to the Dutch and Pontianak, Mempawah's loss of independence and power were considerable. Although the title of Sultan, granted to Nata Kesuma in 1822 (Willer 1857: 70), guaranteed the traditional ruling house a continued presence, Mempawah never regained its full independence from Dutch rule and remained one of the weakest of the native states in the archipelago. As late as 1883 it was said to be one "in which the authority of the Princes is ... restricted within very narrow bounds'. 48

Despite its drawn-out resistance, many of the characteristics of an 18th-century Malay entrepot state in the process of demise as described by Andaya and Andaya (2001: 79-116) seem appropriate for Mempawah in the years under consideration: the benefits and the disruptions caused by the Bugis presence, the political and social problems for royal authority resulting from increased economic opportunities, the presence of anak raja who could only aspire to real authority by competing with existing rulers, and the growing influence of non-Malay groups.

In this study an attempt has been made to describe a number of different perspectives, both by contemporaries and later historians, on the events taking place in Mempawah during the 20 years of its resistance. Traditional Malay histories highlight the Bugis influence in the state, a factor which had dire implications in respect of its relations with the Dutch. Willer, writing some 40 years after the events, provides a local Dutch perspective that is critical of the role of Abd-al Rahman in his campaign against the traditional Malay-Bugis ruling family. Veth, from a more detached viewpoint, follows a standard Dutch line against the Bugis. Different styles and content of contemporary

${ }^{48}$ Struick (1883) quoted and translated in Resink (1968: 338). 
Malay letters reveal the different attitudes of the two sides within the Mempawah state itself. Recent Indonesian writing reflects the authors' own perspectives: Rahman favourably emphasises the strength of Adi Jaya's Islamic beliefs, while Soren, in contrast to the impression conveyed in a contemporary letter of Adi Jaya, stresses Adi Jaya's hatred of the Dutch, rather than of the al-Kadrie.

At this distance, it is neither possible nor necessary to arrive at a single definitive interpretation of events in Mempawah between 1787 and 1808. Drawing as a model one of Raymond Aron's theories of history, it is nevertheless beneficial to comprehend different perspectives even when they seem contradictory. By so doing, one may 'see in their multiplicity a sign not of defeat but of the richness of life' (Aron 1959: 160).

\section{Acknowledgements}

I am grateful to Dr Annabel Gallop for assisting me with source material. Copies of the Malay manuscripts were provided by Leiden University Library. Dr Khasnor Johan made many useful suggestions with regard to the transliteration and translation of the Malay letters. Professor Barbara Andaya, Dr Radin Fernando and two anonymous reviewers read earlier versions of the article and provided much valuable advice. Ms Karina Pelling (Educational and Multimedia Services, College of Asia and the Pacific, ANU) created the maps. Any faults remain mine alone.

\section{References}

\section{Archival sources}

Leiden University Library

Cod. Or. 2239 I 2a. (Letter from Panembahan Syarif Kasim of Mempawah to the G.-G. dated 19 November 1789.)

Cod. Or. 2239 I 3. (Letter from Panembahan Adijaya Kusumah of Karangan to the G.-G. received Batavia January 1790.)

Cod. Or. 2239 I 4. (Letter from the Chiefs of Mempawah to the G.-G., 19 November 1789.)

\section{Publications}

Abdullah, H.W. Muhd. Shaghir. 1982. Upu Daeng Menambon Raja Mempawah dan Saudara-saudaranya [Upu Daeng Menambon, Raja of Mempawah, and his relatives]. Pontianak: Yayasan Pendidikan dan Da'wah Islamiyah Al Fathanah.

Andaya, Leonard Y. 1975. The kingdom of Johor 1641-1728. Kuala Lumpur: Oxford University Press.

Andaya, Barbara Watson. 1997. Adapting to political and economic change: Palembang in the late eighteenth and early nineteenth centuries. In Anthony Reid (ed.), The last stand of Asian autonomies: responses to modernity in the diverse states of Southeast Asia and Korea, 1750-1900. Basingstoke: Macmillan, pp. 187-215.

Andaya, Barbara Watson, and Andaya, Leonard Y. 2001. A history of Malaysia. Basingstoke: Palgrave. 2nd edition. 
Aron, Raymond 1959. Relativism in history. In Hans Meyerhoff (ed.), The philosophy of history in our time: an anthology .... New York: Doubleday, pp. 152-162. (Excerpt from the article on 'The Philosophy of History' in Chambers Encyclopedia, Vol. 7, pp. 147-9).

Barnard, Timothy P. 2003. Multiple centres of authority; society and environment in Siak and eastern Sumatra, 1674-1827. Leiden: KITLV Press.

Braginsky, Vladimir. 2004. The heritage of traditional Malay literature: a historical survey of genres, writings and literary views. Leiden: KITLV Press.

Bronson, Bernet. 1977. Exchange of the upstream and downstream ends; Notes toward a functional model of the coastal state in Southeast Asia. In Karl L. Hutterer (ed.), Economic exchange and social interaction in Southeast Asia: perspectives from prehistory, history and ethnography. Ann Arbor MI: Center for South and Southeast Asian Studies, University of Michigan, pp. 39-52.

Encyclopaedie van Nederlandsch-Indie 1917-1939. The Hague: Nijhoff. 2nd edition.

Fasseur, C. 1993. De Indologen: Ambtenaren voor de Oost, 1825-1950 [The Indologians: civil servants for the East, 1825-1950]. Amsterdam: Bert Bakker.

Goor, J. van. 1986. Seapower, trade and state-formation: Pontianak and the Dutch. In J. van Goor (ed.), Trading companies in Asia 1600-1830. Utrecht: HES.

Hall, D.G.E. 1955. A history of South-East Asia. London: Macmillan.

Heidhues, Mary Somers. 1998. The first two sultans of Pontianak. Archipel 56: 273-294.

Heidhues, Mary Somers. 2003. Golddiggers, farmers and traders in the 'Chinese Districts' of West Kalimantan, Indonesia. Ithaca NY: Southeast Asia Program, Cornell University.

Jackson, James C. 1970. Chinese in the West Borneo goldfields: a study in cultural geography. Occasional Papers in Geography 15. Hull: University of Hull Publications.

Jacobs, Els M. 2006. Merchant in Asia: the trade of the Dutch East India Company during the eighteenth century. Leiden: CNWS Publications.

Kathirithamby-Wells, J. 1993. Hulu-hilir unity and conflict: Malay statecraft in East Sumatra before the mid-nineteenth century. Archipel 45: 77-96.

Kathirithamby-Wells, J. 1997. Siak and its changing strategies for survival, c. 1700-1870. In Anthony Reid (ed.), The last stand of Asian autonomies: responses to modernity in the diverse states of Southeast Asia and Korea, 1750-1900. Basingstoke: Macmillan, pp. 217-243.

Laffan, Michael. 2003. Islamic nationhood and colonial Indonesia: The 'umma' below the winds. London: Routledge Curzon.

Lewis, Dianne. 1995. 'Jan Compagnie' in the Straits of Malacca, 1641-1795. Athens OH: Ohio University, Center for International Studies.

Lopez, A.C. 2010. Of arms and strategy: piracy and the Netherlands Indies government. Review of Indonesian and Malaysian Affairs 44 (1): 191-222.

Matheson, Virginia. 1971. The Tuhfat al-Nafis: structure and sources. Bijdragen tot de Taal, Land- en Volkenkunde van Nederlands-Indie 127 (3): 375-392.

Meursinge, A. 1847. Maleisch Leesboek voor Eerstbeginnenden en meergevorderden ... derde stukje [A Malay reader for beginners and the more advanced ... third piece]. Leiden: Luchtmans.

Milburn, William. 1813. Oriental commerce; containing a geographical description of the principal places in the East Indies, China, and Japan. Also, the rise and progress of the trade of the various European nations with the Eastern world. Vol. 2. London: Black, Perry and Co.

Miller, W.G. 2012. Why did Syarif Kassim kill Captain Sadler at Mempawah in 1795? Journal of the Malaysian Branch of the Royal Asiatic Society 85(1): 63-84. 
Rahman, Ansar, Ja'Achmad, H. and Muhadi (comps.) 2000. Syarif Abdurrahman Alkadri, Perspektif Sejarah Berdirinya Kota Pontianak [Syarif Abdurrahman Alkadri, a perspective on the history of the founding of the town of Pontianak]. Pontianak: Pemerintah Kota Pontianak.

Raja Ali al-Haji. 1926. Silsilah Melayu dan Bugis dan Sakalian Raja-raja-nya ... [A genealogical study of the Malays and Bugis and all their rulers]. Translated by Hans Overbeck. Journal of the Malayan Branch of the Royal Asaitic Society 4 (3): 339-81.

Raja Ali al-Haji. 1973. Silsilah Melayu dan Bugis; disusun dan dikaji oleh Arena Wati [A genealogical study of the Malays and Bugis; compiled and analysed by Arena Wati]. Kuala Lumpur: Pustaka Antara.

Raja Ali Haji ibn Ahmad. 1982. The precious gift (Tuhfat al-Nafis); an annotated translation by Virginia Matheson and Barbara Watson Andaya. Kuala Lumpur: Oxford University Press.

Resink, G.J. 1968. Indonesia's history between the myths: essays in legal history and historical theory. The Hague: W.van Hoeve.

Schulze, Fritz. 1991. Die Chroniken van Sambas und Mempawah: Ein heimische Quellen zur Geschichte West-Kalimantans [The chronicles of Sambas and Mempawah: indigenous sources for the history of West Kalimantan]. Heidelberg: Julius Groos.

Smith, F. Andrew. 2007. An 'arch-villain' to be rehabilitated? Mixed perceptions of Pangeran Anom of Sambas in the early nineteenth century; with an appendix on John Hunt. Borneo Research Bulletin 38: 101-117.

Soren, Ellyas Suryani. 2003. Sejarah Mempawah tempo doeloe [The history of Mempawah in former times]. Pontianak: Kantor Informasi, Arsip dan Perpustakaan Daerah.

Struick, N.J. 1883. De toekomst der inlandsche vorsten op de Buitenbezittingen [The future of the native rulers in the Outer Possessions]. De Indische Gids 5, Part 1: 449-461.

Velde, Paul, van der. 2006. A lifelong passion: P.J. Veth (1814-1895) and the Dutch East Indies. Leiden: KITLV Press.

Veth, P.J. 1854. Borneo's Wester-afdeeling, Geographisch, Statistisch, Historisch ... [Borneo's western division; geographically, statistically, historically]. Vol 1. Zaltbommel: Joh. Noman en Zoon.

Veth, P.J. 1856. Borneo's Wester-afdeeling, Geographisch, Statistisch, Historisch ... Vol 2. Zaltbommel: Joh. Noman en Zoon.

Wieringa, E.P. (comp.) 1998. Catalogue of Malay and Minangkabau manuscripts in the Library of Leiden University and other collections in The Netherlands... comprising the acquisitions of Malay manuscripts in Leiden University Library up to the year 1896, Codices Manuscripti $X X V$. Leiden: Leiden University Library.

Willer, J.T. 1855-1857. Eerste proeve eener kronijk van Mampawa en Pontianak [A preliminary chronicle of Mempawah and Pontianak]. Tijdschrift voor Indische Taal-, Land- en Volkenkunde, III: 516-562 and VI (new series III): 69-74.

\section{Author biography}

W.G. Miller is currently Research Associate in the School of Culture, History and Language, College of Asia and the Pacific, Australian National University. He graduated from the University of Hull with an MPhil in Southeast Asian Studies. He was also Senior Librarian, Southeast Asian Studies at the Australian National University from 1974 to 1997. Email: gmiller@grapevine.com.au 